International

Medical Society

http://imedicalsociety.org
International Archives of Medicine

SECTION: NURSING

ISSN: 1755-7682
2016

Vol. 9 No. 64 doi: $10.3823 / 1935$

\section{Nurses' Job Market Profile in Brazil}

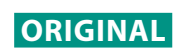

\section{Abstract}

Introduction: The expression 'job market' refers, in general terms, to the dynamics and behavior of the labor force available in the market. It encompasses the relations between employment and unemployment, income levels, working hours, and contractual relations, including wage, workforce distribution in the economy sectors, relations between capital and labor.

Objective: Characterize nurses' job market profile, within the period 2009-2013, in a northeastern Brazilian state.

Method: Descriptive and cross-sectional study, with a quantitative approach and data obtained from two public databases: the Brazilian Social Information Annual Report, by the Brazilian Ministry of Labor and Employment and the number of registrations in the Regional Nursing Council in Rio Grande do Norte, Brazil.

Results: Regarding employment agreements, a certain stability was identified within the period, reducing the number of job positions in 2012 and 2013. When comparing data of nurses' workforce, through records from Regional Nursing Council in Rio Grande do Norte, to job positions of the Brazilian Social Information Annual Report, since 2011, a clear mismatch between the number of job positions and the number of nurses available in the market was found.

Conclusion: It is concluded there is a maintenance trend with worse unemployment, especially among young individuals, if three situations highlighted in 2013 persist: growth in nurses' educational level, staying in Rio Grande do Norte, and stability or maintenance of a decreased number of job positions available.
Jonas Sâmi Albuquerque de Oliveira',

Denise Elvira Pires de Pires², Soraya Maria de Medeiros ${ }^{1}$, Jussara Gue Martini², Karina Cardoso Meira1, Sandra Michelle Bessa de Andrade Fernandes ${ }^{1}$

1 Academic Unit of Life Sciences, Teacher's Training Center, Federal University of Rio Grande do Norte, Natal, Rio Grande do Norte, Brazil.

2 Academic Unit of Life Sciences, Teacher's Training Center, Federal University of Santa Catarina, Florinópolis, Santa Catarina, Brazil.

\section{Contact information:}

Jonas Sâmi Albuquerque de Oliveira.

Address: Academic Unit of Life Sciences, Teacher's Training Center, Federal University of Rio Grande do Norte, Natal, Rio Grande do Norte, Brazil.

\section{” jonassamiufrn@yahoo.com.br}

\title{
Keywords
}

Work; Nurses; Employment; Unemployment. 


\section{Introduction}

The job market expresses, at each social historical time, the outcome of a multidetermined process, strongly influenced by the economic situation [1]. Nurses' job market is a part in this scenario and it is also characterized as a complex phenomenon, particularly influenced by the dynamics of the economy, the health needs, and the policies related to the right and access to health care adopted by the various countries. For analyzing it, there is a need to consider the cyclical situation in each country, the political, economic, and social framework, as well as the specific scenario of the health field and the professions.

Considering the development of capitalist society and the current economic reality, we observe, on the one hand, a great economic development, by producing consumer goods accessible to a part of the society, and, on the other, the social exclusion related to such produced goods. In this society, the economic relations are characterized by an asymmetry of power between those who own the means of production and those that, in order to survive, are forced to sell their labor force [2].

The recent economic crisis has shown a strong impact on employment. Since the late 1960s, the developed capitalist countries experienced a crisis concerning the successful post-Second World War model that disrupted the welfare state and triggered changes in the production mode, so significant that people regard them as a Third Industrial Revolution. It changed the technological basis, with a strong impact of information technology and its applications to various aspects of the production process, as well as the consensus on social rights and the role played by the State in the economy, and big economic blocs redrawing the world geopolitics emerge [3].

More recently, a new international financial crisis has shown up since September 2008, with very negative impacts on developed capitalist countries and it also affected, with a varied intensity, the planet as a whole. Crises affect production, consumption, and the job market, and unemployment is one of their worst outcomes $[4,5]$.

Regarding the impact of the international crisis on the economic activity level and the job market, it is worth noticing that it emerged in different ways in the various countries. In the case in Brazil, this situation began to be realized with a slowdown in gross domestic product (GDP). For the first time between 2000 and 2009, there was a decreased offer of positions in the formal job market, but it did not interfere with the country's favorable status in the international ranking of nations with economic growth. However, the Brazilian situation differed from other countries where the crisis has no effect at all, such as China and India [6].

In Brazil, in 2009, despite the sharp drop in GDP, the job market continued to show improvement, with continuity in the employment formalization process (generating almost 1 million new job positions with a formal contract), income remained in a recovery process and unemployment rates did not grow [7].

Compulsory deposits were allowed, as well as additional provision of resources to the Brazilian National Bank for Economic and Social Development (BNDES), tax relief, housing program, acceleration of other works related to the Brazilian Growth Acceleration Program (PAC), and many credit lines were approved by the official banks. Increased minimum wage has also represented a strong anti-cyclical impact in 2009 [7].

This scenario has influenced the countercyclical measures adopted by the Brazilian government to face the crisis. Such government measures allowed the formal job market to avoid a decrease and, despite the growth stock showed a lower rate, employment kept growing.

When dealing with the generation of jobs in the health sector in Brazil, the Brazilian Institute of Applied Economic Research (IPEA) reported that nurses and the like were responsible for generating 
27,282 job positions, within the period between 2009 and 2012, being characterized as the Higher Education-based profession with the second greater growth in job positions within the period [8].

With a view to knowing nurses' job market behavior and the relation with the availability of these professionals to the market in Rio Grande do Norte, Brazil, this study aimed to characterize nurses' job market profile within the period from 2009 to 2013.

\section{Methodology}

Descriptive and cross-sectional study with a quantitative approach, conducted by means of a secondary, public, data source concerning the job market for nurses and the number of workers available to the market. This study realized one state in northeastern Brazil, by analyzing a historical series related to the number of nurses who are employed in the state and the total amount of professionals qualified for the job market within the same period. To do this, we analyzed the number of workers registered in the Brazilian Social Information Annual Report (RAIS), by the Ministry of Labor and Employment (MTE), and the number of nurses registered in the Regional Nursing Council in Rio Grande do Norte, Brazil (COREN/RN).

Data were collected in two stages. In the first stage a search was carried out on the database of the RAIS (http://bi.mte.gov.br/bgcaged/caged anuario rais/anuario.htm). The RAIS was an administrative record that covers the universe of formal jobs, including workers with a formal contract, according to the Brazilian Consolidation of Labor Laws (CLT), statutory and military civil servants, and the other agreements related to the public administration [9].

The RAIS is provided with data by all employing companies in the country, which inform to the MTE the set of job movements in the reference year. This information is computed and disseminated by the MTE with the total amount of active and inactive employment agreements on the last day of the year. The data from the RAIS cover about $97.0 \%$ of the Brazilian formal job market, and, in practice, this is a census on this population [10].

To collect data from the RAIS, we used a structured instrument, prepared by the researchers. The following variables were extracted: number, type, and legal nature of the employment agreements; age group and gender of the employed nurses; working hours and wage; as well as the number of municipalities with nurses and the frequency of nurses per municipality.

The collection of data related to these variables occurred after the completion of registration in the website of the MTE, generating a password for accessing the RAIS database and it this allowed us to extract data from the RAIS (Figure 1).

In the second stage, data were collected on the COREN/RN, with the following variable: total amount of enrolled nurses on December 31, from 2009 to 2013

Figure 1: Data search and extraction flow in the RAIS database. .

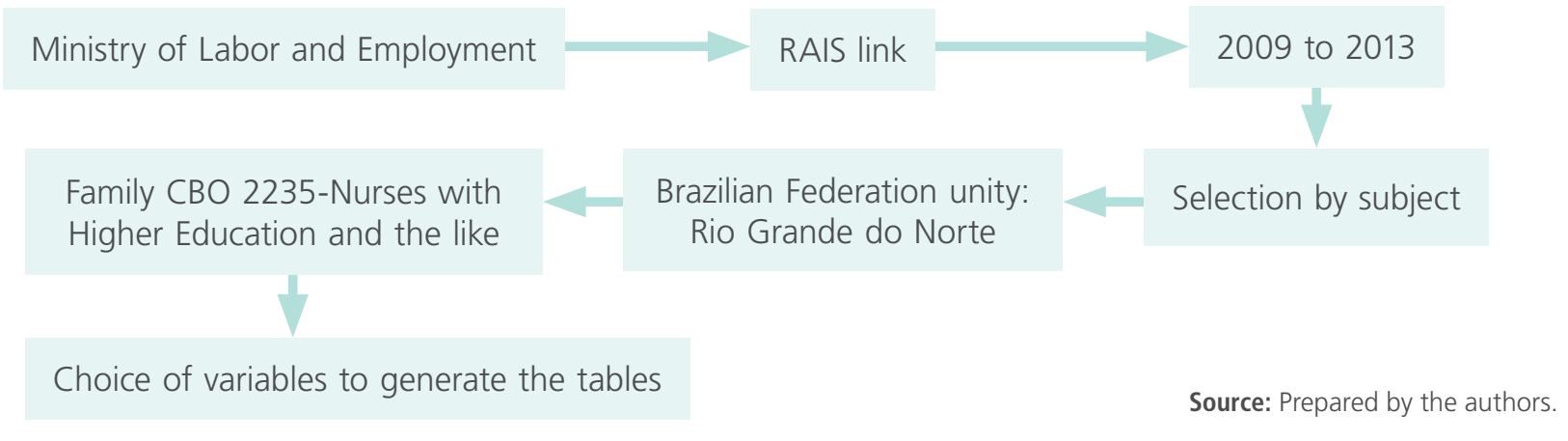


Data were collected on the two databases between December 2014 and January 2015. After the collection, data were entered to a database in the software Microsoft Excel, version 2010, and a dictionary was prepared (codebook). In this software, a double feed validation process was conducted through two independent typing procedures, in two spreadsheets, then data underwent processing by using descriptive statistics. The analysis was conducted with the aid of the software Statistical Package for the Social Sciences (SPSS), version 19.0, for extracting simple and percentage frequencies.

The number of formal employment agreements among nurses from 2009 to 2013 obtained from the RAIS was analyzed in association with that of nurses registered in the COREN/RN in the same years. In all assessment instruments applied, the scores were turned into a percentage scale from 0 to $100 \%$. The scores shown herein are more satisfactory the closer they get to 100 .

\section{Results}

\section{Employment agreements for nurses in Rio Grande do Norte, Brazil}

Considering 167 as the number of municipalities in the state of Rio Grande do Norte, Brazil, there was an increasing entry of nurses within the period used as a basis for this study. It was found that, in 2009, 117 of the municipalities (70.06\%) had nurses. In 2010, this number increased to 126 (75.45\%); in 2011, they were already 134 municipalities in Rio Grande do Norte (80.24\%) with nurses, and they reached 137 (82.04\%) in 2012. In 2013, the last year that provided this study with a basis, there were 142 municipalities in the state (85.03\%) that already had nurses with an employment agreement. Concerning the location of municipalities with nurses in Rio Grande do Norte, data revealed a predominance of job positions in urban areas.

As for the evolution in the number of employment agreements, there was an increase in 2009, 2010, and 2011 and a decrease in 2012 and 2013. In relation to gender, a strong predominance of women was identified.

In terms of the legal nature of employment agreements, the findings of this study revealed the presence of eight categories (Table 1).

In general, it is observed in Table 1 that the higher frequencies are related to nurses employed by the public sector, at the three government levels: federal, state, and municipal. Employment in the federal public sector remained relatively stable with some growth between 2009 and 2013. In the sta-

Table 1. Legal nature of nurses' employment agreements in Rio Grande do Norte, Brazil (2009-2013).

\begin{tabular}{|c|c|c|c|c|c|c|c|c|c|c|}
\hline \multirow{2}{*}{ Legal Nature of Agreements } & \multicolumn{2}{|c|}{2009} & \multicolumn{2}{|c|}{2010} & \multicolumn{2}{|c|}{2011} & \multicolumn{2}{|c|}{2012} & \multicolumn{2}{|c|}{2013} \\
\hline & $\mathrm{n}$ & $\%$ & $n$ & $\%$ & $n$ & $\%$ & $\mathrm{n}$ & $\%$ & $n$ & $\%$ \\
\hline Federal Public Sector & 203 & 9.97 & 174 & 7.67 & 191 & 7.51 & 197 & 8.06 & 242 & 10.77 \\
\hline State Public Sector & 689 & 33.82 & 775 & 34.17 & 797 & 31.33 & 790 & 32.32 & 89 & 3.96 \\
\hline Municipal Public Sector & 586 & 28.77 & 684 & 30.16 & 876 & 34.43 & 690 & 28.23 & 1.035 & 46.04 \\
\hline Public Sector - Other & 0 & 0.00 & 0 & 0.00 & 1 & 0.04 & 4 & 0.16 & 6 & 0.27 \\
\hline State Company Entity & 7 & 0.34 & 7 & 0.31 & 8 & 0.31 & 8 & 0.33 & 8 & 0.36 \\
\hline Private Company Entity & 442 & 21.70 & 472 & 20.81 & 500 & 19.65 & 561 & 22.95 & 697 & 31.01 \\
\hline Nonprofit Entities & 110 & 5.40 & 156 & 6.88 & 170 & 6.68 & 192 & 7.86 & 168 & 7.47 \\
\hline $\begin{array}{l}\text { Natural Persons and Other Legal } \\
\text { Organizations }\end{array}$ & 0 & 0.00 & 0 & 0.00 & 1 & 0.04 & 2 & 0.08 & 3 & 0.13 \\
\hline Total & 2,037 & 100 & 2,268 & 100 & 2,544 & 100 & 2,444 & 100 & 2,248 & 100 \\
\hline
\end{tabular}


te public sector there was a significant decrease in employment agreements, especially since 2012, dropping from $32.32 \%$ in 2012 to $3.96 \%$ in 2013 . At the same time, throughout the study period, the number of employment agreements in the municipal public sector grew annually from 2009 to 2013, with a significant boost between 2012 (28.23\%) and 2013 (46.04\%).

The second highlight, in relation to the legal nature of agreements, was the private sector, which showed up as the second most important employer.
The behavior of employment in this sector, within the period under study, showed some stability but an increased number of agreements between 2009 (21.70\%) and 2013 (31.01\%).

The third position concerning the number of agreements was held by the nonprofit entities, which kept some growth over the period, reaching 2013 with 7.47\% of nurses' agreements.

As for the types, the RAIS ranks 17 employment agreements, however, the research data showed that nurses fit into 13 of them (Table 2).

Table 2. Types of employment agreements for nurses in Rio Grande do Norte, Brazil (2009-2013).

\begin{tabular}{|c|c|c|c|c|c|c|c|c|c|c|}
\hline \multirow{2}{*}{ Types of Agreement/Year } & \multicolumn{2}{|c|}{2009} & \multicolumn{2}{|c|}{2010} & \multicolumn{2}{|c|}{2011} & \multicolumn{2}{|c|}{2012} & \multicolumn{2}{|c|}{2013} \\
\hline & $\mathrm{n}$ & $\%$ & $n$ & $\%$ & $\mathrm{n}$ & $\%$ & $n$ & $\%$ & $n$ & $\%$ \\
\hline Statutory & 1,127 & 55.33 & 1,137 & 50.13 & 1,142 & 44.89 & 1,145 & 46.85 & 655 & 29.14 \\
\hline Provisional & 8 & 0.39 & 1 & 0.04 & 43 & 1.69 & 30 & 1.23 & 8 & 0.36 \\
\hline $\begin{array}{l}\text { Statutory - Brazilian General Social } \\
\text { Security Regime (RGPS) }\end{array}$ & 47 & 2.31 & 75 & 3.31 & 190 & 7.47 & 182 & 7.45 & 252 & 11.21 \\
\hline Non-member statutory & 242 & 11.88 & 359 & 15.83 & 408 & 16.04 & 273 & 11.17 & 297 & 13.21 \\
\hline Director & 0 & 0.00 & 0 & 0.00 & 0 & 0.00 & 0 & 0.00 & 0 & 0.00 \\
\hline $\begin{array}{l}\text { Previously determined provisional } \\
\text { agreement }\end{array}$ & 0 & 0.00 & 4 & 0.18 & 2 & 0.08 & 0 & 0.00 & 0 & 0.00 \\
\hline Previously determined agreement & 25 & 1.23 & 27 & 1.19 & 39 & 1.53 & 9 & 0.37 & 65 & 2.89 \\
\hline Municipal Law Agreement & 7 & 0.34 & 20 & 0.88 & 23 & 0.90 & 27 & 1.10 & 33 & 1.47 \\
\hline State Law Agreement & 0 & 0.00 & 0 & 0.00 & 0 & 0.00 & 0 & 0.00 & 0 & 0.00 \\
\hline $\begin{array}{l}\text { Brazilian Consolidation of Labor Laws } \\
\text { - Urban - Non-previously determined } \\
\text { legal entity (CLT U/PJ Indeterminate) }\end{array}$ & 575 & 28.23 & 639 & 28.17 & 686 & 26.97 & 763 & 31.22 & 919 & 40.88 \\
\hline $\begin{array}{l}\text { Brazilian Consolidation of Labor Laws } \\
\text { - Urban - Previously determined legal } \\
\text { entity (CLT U/PJ Determined) }\end{array}$ & 2 & 0.10 & 3 & 0.13 & 8 & 0.31 & 7 & 0.29 & 6 & 0.27 \\
\hline $\begin{array}{l}\text { Brazilian Consolidation of Labor } \\
\text { Laws - Urban - Non-previously } \\
\text { determined natural persons (CLT U/PF } \\
\text { Indeterminate) }\end{array}$ & 0 & 0.00 & 0 & 0.00 & 1 & 0.04 & 3 & 0.12 & 4 & 0.18 \\
\hline $\begin{array}{l}\text { Brazilian Consolidation of Labor Laws } \\
\text { - Urban - Previously determined } \\
\text { natural persons (CLT U/PF Determined) }\end{array}$ & 0 & 0.00 & 0 & 0.00 & 0 & 0.00 & 0 & 0.00 & 0 & 0.00 \\
\hline $\begin{array}{l}\text { Brazilian Consolidation of Labor } \\
\text { Laws - Rural - Non-previously } \\
\text { determined natural persons (CLT R/PJ }\end{array}$ & 4 & 0.20 & 0 & 0.00 & 2 & 0.08 & 5 & 0.20 & 1 & 0.04 \\
\hline
\end{tabular}




\section{Types of Agreement/Year}

\section{\begin{tabular}{|l|l|l|l|}
\multicolumn{2}{|c|}{2009} & \multicolumn{2}{c}{2010} \\
\hline$n$ & $\%$ & $n$ & $\%$ \\
\hline
\end{tabular}}

\begin{tabular}{|l|l|}
\hline \multicolumn{2}{|c}{2011} \\
\hline$n$ & $\%$
\end{tabular}

$n^{2012}$

2012

$\%$

\begin{tabular}{|l|l|}
\hline \multicolumn{2}{|c|}{2013} \\
\hline$n$ & $\%$ \\
\hline
\end{tabular}

Brazilian Consolidation of Labor Laws

- Rural - Previously determined natural persons (CLT R/PJ Determined)

\begin{tabular}{|l|c|c|c|c|c|c|c|c|c|c|}
\hline Detached & 0 & 0.00 & 0 & 0.00 & 0 & 0.00 & 0 & 0.00 & 4 & 0.18 \\
\hline Apprentice & 0 & 0.00 & 0 & 0.00 & 0 & 0.00 & 0 & 0.00 & 0 & 0.00 \\
\hline Total & 2,037 & 100 & 2,268 & 100 & 2,544 & 100 & 2,444 & 100 & 2,248 & 100 \\
\hline
\end{tabular}

Source: Prepared by the authors.

Among the agreements, the largest number found referred to the group of statutory nurses (including the specifications: statutory, statutory under the Brazilian General Social Security Regime, and non-member statutory) corresponding to $53.56 \%$ in 2013. When comparing the frequency per year of jobs described in the regime known only as 'statutory' for nurses in Rio Grande do Norte, there was a sharp decrease in this type of agreement between 2012 (46.85\%) and 2013 (29.14\%). However, most of nurses' agreements in the state fall into the statutory categories.

The second group consists in the contracts governed by the CLT (including: previously determined agreement, non-previously determined agree- ment, natural person, legal entity, and urban and rural workers), totaling, in 2013, 41.37\%. It is worth highlighting that almost all CLT agreements are within the "urban workers, legal entity, and nonpreviously determined" category. Considering the behavior of CLT agreements within the period, there was an increase from $28.23 \%$ in 2009 to $40.88 \%$ in 2013.

Data on nurses' age group, working hours, and average wage in the state of Rio Grande do Norte, within the period from 2009 to 2013, are shown in Table 3.

Out of the total number of nurses in Rio Grande do Norte with an active employment agreement, according to the RAIS, in relation to the age group,

Table 3. Nurses' age group, working hours, and average wage in Rio Grande do Norte, Brazil (2009-2013).

\begin{tabular}{|c|c|c|c|c|c|c|c|c|c|c|}
\hline \multirow{2}{*}{ Variables/Year } & \multicolumn{2}{|c|}{2009} & \multicolumn{2}{|c|}{2010} & \multicolumn{2}{|c|}{2011} & \multicolumn{2}{|c|}{2012} & \multicolumn{2}{|c|}{2013} \\
\hline & $n$ & $\%$ & $n$ & $\%$ & $\mathrm{n}$ & $\%$ & $\mathrm{n}$ & $\%$ & $\mathrm{n}$ & $\%$ \\
\hline \multicolumn{11}{|l|}{ Age group (years) } \\
\hline $16^{\star}$ to 24 & 107 & 5.25 & 137 & 6.04 & 142 & 5.58 & 90 & 3.68 & 100 & 4.45 \\
\hline 25 to 29 & 341 & 16.74 & 476 & 20.99 & 598 & 23.51 & 526 & 21.52 & 548 & 24.38 \\
\hline 30 to 39 & 519 & 25.48 & 587 & 25.88 & 672 & 26.42 & 718 & 29.38 & 823 & 36.61 \\
\hline 40 to 49 & 597 & 29.31 & 593 & 26.15 & 586 & 23.03 & 538 & 22.01 & 424 & 18.86 \\
\hline 50 to 64 & 459 & 22.53 & 455 & 20.06 & 525 & 20.64 & 550 & 22.50 & 336 & 14.95 \\
\hline$\geq 65$ & 14 & 0.69 & 20 & 0.88 & 21 & 0.83 & 22 & 0.90 & 17 & 0.76 \\
\hline \multicolumn{11}{|l|}{ Working hours } \\
\hline Up to 12 & 6 & 0.29 & 6 & 0.26 & 27 & 1.06 & 6 & 0.25 & 28 & 1.25 \\
\hline 16 to 20 & 37 & 1.82 & 36 & 1.59 & 34 & 1.34 & 27 & 1.10 & 225 & 10.01 \\
\hline 21 to 30 & 128 & 6.28 & 132 & 5.82 & 227 & 8.92 & 217 & 8.88 & 273 & 12.14 \\
\hline 31 to 40 & 1,423 & 69.86 & 1,594 & 70.28 & 1,704 & 66.98 & 1,719 & 70.34 & 1,126 & 50.09 \\
\hline 41 to 44 & 443 & 21.75 & 500 & 22.05 & 552 & 21.70 & 475 & 19.44 & 596 & 26.51 \\
\hline
\end{tabular}




\begin{tabular}{|c|c|c|c|c|c|c|c|c|c|c|}
\hline \multirow{2}{*}{ Variables/Year } & \multicolumn{2}{|c|}{2009} & \multicolumn{2}{|c|}{2010} & \multicolumn{2}{|c|}{2011} & \multicolumn{2}{|c|}{2012} & \multicolumn{2}{|c|}{2013} \\
\hline & $\mathrm{n}$ & $\%$ & $\mathrm{n}$ & $\%$ & $\mathrm{n}$ & $\%$ & $\mathrm{n}$ & $\%$ & $n$ & $\%$ \\
\hline \multicolumn{11}{|c|}{ Average wage (minimum wage) ${ }^{\star *}$} \\
\hline Up to 0.50 & 5 & 0.25 & 7 & 0.31 & 2 & 0.08 & 6 & 0.25 & 3 & 0.13 \\
\hline 0.51 to 1.00 & 9 & 0.44 & 12 & 0.53 & 20 & 0.79 & 9 & 0.37 & 11 & 0.49 \\
\hline 1.01 to 1.50 & 47 & 2.31 & 54 & 2.38 & 59 & 2.32 & 48 & 1.96 & 60 & 2.67 \\
\hline 1.51 to 2.00 & 38 & 1.87 & 39 & 1.72 & 58 & 2.28 & 61 & 2.50 & 78 & 3.47 \\
\hline 2.01 to 3.00 & 175 & 8.59 & 210 & 9.26 & 188 & 7.39 & 199 & 8.14 & 307 & 13.66 \\
\hline 3.01 to 4.00 & 221 & 10.85 & 271 & 11.95 & 346 & 13.60 & 518 & 21.19 & 614 & 27.31 \\
\hline 4.01 to 5.00 & 343 & 16.84 & 411 & 18.12 & 496 & 19.50 & 421 & 17.23 & 415 & 18.46 \\
\hline 5.01 to 7.00 & 467 & 22.93 & 533 & 23.50 & 579 & 22.76 & 477 & 19.52 & 357 & 15.88 \\
\hline 7.01 to 10.00 & 451 & 22.14 & 442 & 19.49 & 409 & 16.08 & 413 & 16.90 & 189 & 8.41 \\
\hline 10.01 to 15.00 & 247 & 12.13 & 211 & 9.30 & 274 & 10.77 & 189 & 7.73 & 126 & 5.60 \\
\hline 15.01 to 20.00 & 25 & 1.23 & 48 & 2.12 & 66 & 2.59 & 69 & 2.82 & 62 & 2.76 \\
\hline More than 20.00 & 5 & 0.25 & 27 & 1.19 & 44 & 1.73 & 25 & 1.02 & 22 & 0.98 \\
\hline Unclassified & 4 & 0.20 & 3 & 0.13 & 3 & 0.12 & 9 & 0.37 & 4 & 0.18 \\
\hline Total & 2,037 & 100 & 2,268 & 100 & 2,544 & 100 & 2,444 & 100 & 2,248 & 100 \\
\hline
\end{tabular}

Source: Prepared by the authors

*: Age considered for the first job in the area.

**: As for the variable average wage, it was based on the Brazilian minimum wage in effect within the data collection period of this research (R\$678.00) (BRASIL, 2014).

it was found that the lower frequencies are among young people and the individuals $\geq 65$ years.

Young people aged between 16 and 24 years totaled, in 2013, 100 nurses, corresponding to $4.45 \%$ of the total employment agreements. Within this period, there was some fluctuation in the percentage of young people employed, with a decrease between 2009 (5.25\%) and 2013 (4.45\%). The nurses aged above 50 years totaled, in 2013, 15.71\% of the employment agreements.

The great predominance was among young adults and those at mature age, i.e. from 25 to 49 years, totaling, in $2013,79.85 \%$ of the nurses employed in the state.

As for nurses' working hours in Rio Grande do Norte, it was found, in 2013, that the weekly working hours above 30 hours accounted for the higher frequencies of the existing agreements, totaling $76.60 \%$ of these workers. In the same year, a very small number, $1.25 \%$ of the total number of employed nurses, had up to 12 working hours per week and a total of $22.15 \%$ had between 16 and 30 working hours per week. It is worth noticing that, within the period, the number of workers who had between 16 and 30 working hours per week increased.

Regard wage, based on the minimum wage of $R \$ 678.00$ in 2013, corresponding to the value in the Brazilian currency, Table 3 describes the frequency of wages earned by nurses between 2009 and 2013 in Rio Grande do Norte. According to Table 3, it is observed that, in 2013, the number of Higher Education-based nursing professionals in the state earned wages for carrying out their labor activities within the range from 2.01 to 7.00 minimum wages, totaling $75.31 \%$ of this workforce $(R \$$ $1,356.00$ to $4,746.00$ ).

Considering the set of employed nurses, it is observed that, throughout the period, there were nurses earning less than 1 minimum wage. In 2013, those earning up to 1 minimum wage amounted to $0.62 \%$ of this workforce. It is also worth noticing, 
at the other end, there are also a small number (9.34\%, in 2013) of nurses earning above $10 \mathrm{mi}-$ nimum wages ( $R \$ 6,780.00)$. And only $4(0.98 \%)$ earned more than 20 minimum wages, in 2013.

\section{Number of nurses available versus existing job positions}

The outcomes of this second axis are related to the comparison of findings of data collected on the databases of the RAIS and the COREN/RN.

The findings on the COREN/RN inform the number of nurses enrolled, i.e. the number of nurses qualified to pursue the profession. And data from the RAIS show the movements of job positions made available by companies that employ nurses in Rio Grande do Norte.

The association of findings on the two databases shown in Figure $\mathbf{2}$ allows us to make inferences about nurses' job market behavior in Rio Grande do Norte.

When comparing data made available regarding nurses' workforce, through records from the COREN/RN, with the job positions registered in the RAIS, since 2011, a clear mismatch between the number of job positions and the number of nurses available in the job market was found. While there

Figure 2: Number of registrations in COREN/RN and nurses' formal active agreements per year in Rio Grande do Norte, Brazil (2009-2013).

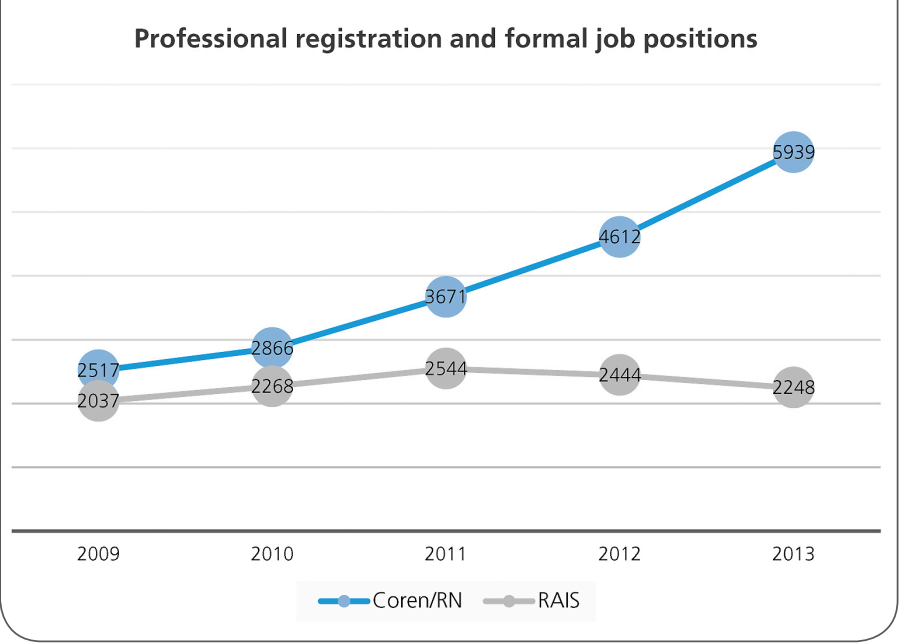

is some stability followed by a drop in the number of jobs, since 2011, a steady growth in the number of nurses available in the job market was noticed, with a large increase since 2010.

\section{Discussion}

Nurses' job market behavior has been the subject of current concern among scholars around the world, especially in developed countries. In these studies, we notice trends of migration, scarcity, increase, and, at the same time, decrease in job positions, ease and also difficulty for getting into the workplace and changes in contractual arrangements.

Nurses' job market in Rio Grande do Norte showed that, unlike the migration data found in the international literature, an increasing number of nurses graduated in the state, especially after the number of Higher Education institutions started to grow, since 2004, have remained in the state [11, 12]. According to data on nurses qualified for professional practice in Rio Grande do Norte, nurses registered in the COREN/RN remain available or they get into the job market of this state.

By analyzing the relation between job positions registered in the RAIS and the number of nurses registered in the COREN/RN, there is a mismatch signaling an unemployment scenario. Having in mind the maintenance of the current scenario, with an increase in the number of graduated professionals, their permanence in the job market in the state, and stability or decrease in the number of job positions available, a worrying scenario of increased unemployment in the next period may emerge. It is worth noticing that this situation is even more dramatic concerning newly graduated young individuals. The findings of this research are close to what was observed in the national and international literature on the exclusion and/or difficulty of young people to get into the current job market.

The first job, which constitutes a key issue both in the young individual's decision and from the 
family perspective, has significant national implications when thinking of a new transition phase of the society. When considering the number of young individuals, Brazil ranks fifth in the world. This ranking brings the country to the scenario of young people who depend on parents at the economic level to a large extent, due to the absence of jobs for this age group. It is worth noticing that even young people who are more capable to get into the job market than their parents, as for educational level and vocational education, are frustrated because of recurrent unemployment, or desolated in face of low pay occupation, which prevents them from achieving economic independence [13].

The predominance of nurses' employment agreements in Rio Grande do Norte took place within the public sector, with a greater concentration in the municipal public sector. This piece of information seems to be related to the government policies aimed at increasing health access in Brazil, post-1988 Constitution, creation of the Brazilian National Health System (SUS) and the Brazilian Family Health Program (PSF), then named as the Brazilian Family Health Strategy (ESF). The ESF has been systematically expanded in the country, especially since 2004, and also in Rio Grande do Norte [9, 14].

In the whole set of availability of job positions, which has been relatively stable with a slight decrease between 2012 and 2013, unlike the growing number of graduated nurses, the scenario in Rio Grande do Norte resembles that observed in other countries, with a relation between market and economic performance.

In this regard, the international literature shows there is a relation between economic crisis and shortage of resources for hiring personnel in hospitals within the public sector. In post-2008 period, there were common problems, such as: decreased GDP, decreased government budgets, decreased investment in health and increased unemployment, especially among young people [15-20].
The economic reform aimed at the market has provided fewer resources available for hiring several professionals in many countries of Eastern Europe, Central Asia, and Latin America. This scenario of lower investment in human resources generates hiring freeze, with an impact on nurses' workforce and a tendency to maintain or reduce the number of these professionals [21-24].

Despite data from the RAIS does not show a significant presence of labor precariousness among nurses in the scenario under study, there is a need for further research about this phenomenon, which the very design of this research may have failed to capture. The reference to the issue of labor precariousness has been motivated by data from the literature related to the current labor world and also by the types of nurses' employment agreements in other countries $[25,26]$. In this regard, the predominance of casual work, i.e. occasional work in more than $90 \%$ of nurses' agreements in the country [27].

In terms of working hours in nurses' employment agreements in Rio Grande do Norte, it was found that, despite the fight put up by nursing professionals to regulate their working hours as 30 hours per week, most nurses in the state (76.60\%) have more than 30 working hours per week.

Concerning nurses' wages in Rio Grande do Norte, data from the RAIS show a big wage gap, also in relation to what has been claimed by the category. provided for by a bill presented to the Brazilian National Congress in 2009 (PL 4,924/2009), which addresses the wage of nursing professionals, nurse, nursing technician, nursing assistant, and midwife. This bill proposed in 2009 a $\mathrm{R} \$ 4,450.00$ wage floor (value set to be readjusted according to the accumulated variation in the Brazilian National Consumer Price Index (INPC) [28].

\section{Final considerations}

Considering the scenario in the state under study, research findings point out an unemployment trend 
in the area, if three factors that were clearly evidenced in 2013 persist: growth in nurses' educational level, staying in Rio Grande do Norte, and stability or maintenance of a decreased number of job positions available. This phenomenon tends to be more severe among the young population that is more fragile both concerning professional experience to compete for the best jobs and in terms of their vulnerability issue, due to the need for income, leading them to undergo unstable job positions, provisional, part-time, as well as the various forms of underemployment.

The outcomes point out the immediate need for claims by the professional category regarding an increased number of job positions for nurses, as well as strengthened prioritization mechanisms of employment generation incentive policies for young people, by means of greater attention to the first job in the profession. However, it is also crucial to invest in appreciating public service workers, having in mind the strengthening of SUS, which starts from the maintenance of statutory agreements and reduction of the other modes of contractual arrangements, investment in better wages, and deployment of plans regarding job positions and wages, establishment of working hours and wage floor compatible with the profession, encouraging professional qualification.

Data show that further studies in this field may support changes in the setting of trends in nurses' job market, having in mind the economic, political, context and health care prioritization measures in a scenario of need for nurses to provide people with care, especially those in need of care within the primary health care and those undergoing impacts triggered by the maintenance and/or epidemiological and demographic changes.

\section{Acknowledgments}

The authors thank to the COREN/RN for the approval and availability regarding the use of its database, indispensable to this study.

\section{References}

1. Silva LMO, Dedecca CS. Dimensão e características do mercado de trabalho no macrocomplexo da saúde brasileira. Revista da ABET. 2014; 6(2): 1-36.

2. Belluzzo LG. O capital e suas metamorfoses. São Paulo, SP: Unesp; 2013.

3. Pires D. Reestruturação produtiva e trabalho em saúde no Brasil. 2. ed. São Paulo, SP: Annablume; 2008.

4. ILO. Global Employment Trends. Geneva: International Labour Office, January; 2009.

5. Organização Internacional do Trabalho (OIT). Brasil, uma estratégia inovadora de crescimento com equidade. Genebra: Organização Internacional do Trabalho. Instituto Internacional de Estudos do Trabalho; 2011.

6. Departamento Intersindical de Estatísticas e Estudos Socioeconômicos (DIEESE). Estudo setorial da construção. São Paulo, Estudos e Pesquisas, 56; 2011

7. Departamento Intersindical de Estatísticas e Estudos Socioeconômicos (DIEESE). Resultados da gestão orçamentária e financeira do Estado do Rio Grande do Norte: análise comparativa, Período: 2010 a 2014; 2012.

8. Instituto de Pesquisas Econômicas e Aplicadas (IPEA). Ranking traz ocupações com os maiores salários; 2013.

9. Brasil. Ministério da Saúde. Secretaria de Atenção à Saúde. Departamento de Atenção Básica. Nota técnica. Informações sobre as ações e programas do Departamento de Atenção Básica do Rio Grande do Norte. Brasília: Editora do Ministério da Saúde; 2015.

10. Brasil. Ministério do Trabalho. Relação Anual de Informações Sociais (RAIS) do Ministério do Trabalho e Emprego. Brasília; 2015.

11. Freeman M. et al. Migration: a concept analysis from a nursing perspective. Journal of advanced nursing. 2011; 68(5): 1176-86.

12. Brasil. Empregabilidade e Trabalho dos Enfermeiros no Brasil. Relatório Final. RH/IMS - UERJ; 2004

13. Pochmann M. A batalha pelo primeiro emprego. São Paulo, SP: Publisher Brasil; 2007.

14. Brasil. Ministério da Saúde. Secretaria de Atenção à Saúde. Departamento de Atenção Básica. Nota técnica. Informações sobre as ações e programas do Departamento de Natal; 2015.

15. Buchan J, O'May F, Dussault G. Nursing workforce policy and the economic crisis: a global overview. Journal of advanced nursing. 2013; 45(3): 298-307. 
16. Zurn P, Dokea C, Stilwell B. Nurse retention and recruitment: developing a motivated workforce. Geneva, International Council of Nurses; 2005.

17. Fang ZZ. Potential of China in global nurse migration. Health Serv Res. 2007; 42(3): 31419-28.

18. Suwandono A, Achadi A, Arystami K. Human resources on health for foreign countries: A case of nurse "surplus" in Indonesia. Asia-Pacific Action Alliance on Human Resources for Health; 2005

19. Zarea K, Negaradeh R, Dehghan-Nayeri N, Reznei-Adaryani M. Nursing staff shortages and job satisfaction in Iran: Issues and challenges. Nursing and Health Sciences. 2009; 11(1): 326-331.

20. Squires A, Beltrá-Sánchez H. Predicting Nursing Human Resources: An Exploratory Study. Policy, Politics, \& Nursing Practice. 2009; 10 (2): 101-9.

21. Dovlo D. Wastage in the health workforce: Some perspectives from African countries. Human Resources for Health. 2005; 1(3): 6-14.

22. International Council of Nurses (ICN). Fact Sheet: An Ageing Nursing Workforce. Geneva, ICN; 2007.

23. Liese B, Dussault G. The state of the health workforce in SubSaharan Africa: Evidence of crisis and analysis of contributing factors. DC, World Bank. Washington; 2004.

24. Buchan J, Calman L. The global shortage of registered nurses: an overview of issues and actions. International Council of nurses. Geneva; 2004.

25. Roso SD. Crise econômica e intensificação do trabalho in Riqueza e Miséria do trabalho no Brasil II. Org. Ricardo Antunes. 1 ed. São Paulo, SP: Bointempo; 2013.

26. Antunes R. Riqueza e miséria do trabalho no Brasil II. Org. Ricardo Antunes. 1 ed. São Paulo, SP: Bointempo; 2013.

27. Tommaso ML, Strom S, Saether EM. Nurses wanted is the job too harsh or is the wage too low? Journal of Health Economics. 2009; 28(3): 546-53.

28. Pires D, LopeS MGD, Silva MCN, Lorenzetti J, Peruzzo AS, Resciani HR. Jornada de 30 horas semanais: condição necessária para assistência de enfermagem segura e de qualidade. Rev. Enfermagem em Foco. 2010; 1(3):114-118

Publish in International Archives of Medicine

International Archives of Medicine is an open access journal publishing articles encompassing all aspects of medical science and clinical practice. IAM is considered a megajournal with independent sections on all areas of medicine. IAM is a really international journal with authors and board members from all around the world. The journal is widely indexed and classified Q1 in category Medicine. 